\title{
Imperfect Forms and the Taxonomy of Mallomonas
}

\author{
By KATHARINE HARRIS \\ Botany Department, University of Reading, Reading, Berkshire
}

(Accepted for publication 13 December 1969)

SUMMARY

This paper deals with taxonomic problems caused by the occurrence in nature of forms of Mallomonas species which are considered to be stages in development. They are called 'imperfect' forms; that is, forms that lack features that have been included in the diagnosis. These individuals might be described as separate species except when intermediate forms are noticed which link them with the perfect form of diagnosed species. The fine details of their scales are the same as in the perfect form.

\section{INTRODUCTION}

Mallomonas is a large genus of the Chrysophyceae, a class of algae with golden green chromatophores. Authors differ in the way they subdivide the Chrysophyceae but the genus Mallomonas is usually placed near such familiar genera as the colonial Synura and less close to Dinobryon. Mallomonas is an elegant flagellate possessing a single flagellum and a cell covered with silica scales whose shape and elaborate markings have proved to be specific in their pattern. The scales may have a rigid prolongation, a spine, and may bear a single mobile hinged bristle which is readily detachable. Certain stages of the organism differ considerably from the mature forms. The development of such 'imperfect' forms has been traced as far as it could be in the wild and in samples of natural waters kept under observation for a few weeks. These forms may have caused a good deal of taxonomic confusion. Imperfect forms may be found in all Mallomonas species. They are mainly seen during a period of rapid cell division or 'swarming'. I describe a few of the most commonly found forms having selected them chiefly because they might lead to taxonomic confusion. Undoubtedly these forms have their place in the life-cycle of the species concerned, but this must be studied by other methods than those used here.

Before the advent of the electron microscope the species were based on the shape and size of the cell together with the character and distribution of the bristles and such information about the scales as the microscope of the day could provide. In 1955 Fott published the first electron micrograph of a Mallomonas scale; this was followed by a similar publication by Asmund (1955). Thus a whole new range of taxonomic facts was revealed, the scale and its markings becoming the ultimate criterion of the species. In my view the diagnosis of a Mallomonas species without an electron micrograph of the scale is now out of date. 


\section{OBSERVATIONS}

One may base the study of a Mallomonas species on a large population of welldeveloped (perfect) individuals and if a few small or unusual ones are present these will be disregarded. However, imperfect organisms are sometimes abundant and I have noticed that when such a sample is kept in a shady place out of doors the imperfect forms may become few and the perfect ones predominate.

All the torquata group of species have an armour made of three sorts of scale, a few triangular scales with or without bristles, forming a collar, a number of rhomboidal scales forming the body and a few small scales at the rear. Often the rearmost of these has a corner drawn out into a point, ridge or spine. In the commonest imperfect form the collar and rear scales are the same in size and number as in the perfect form but the body scales though of the normal size are few, so that such an organism will be small. The perfect cell also has scales that fit together and form a coherent armour which does not collapse on drying while the scales of the imperfect form overlap and the armour collapses on drying unless the cell has first been fixed. Plate I, fig. I-4 illustrate these forms of Mallomonas pumilio, Pl. I, fig. 2, a replica, shows the way the scales fit together, and Pl. I, fig. 4, a fixed cell, shows the overlap. Plate I, fig. 5 and 6 show $M$. mangofera in imperfect and perfect forms.

Fig. I $a$, and $b$, illustrate another type of imperfection which has been seen in Mallomonas pumilio and in other species of Mallomonas, though much more rarely. In this the scales appear in the front only, leaving the rear naked. I think it likely that these organisms have emerged recently from the cyst.

Mallomonas heterospina Lund 1942 e.m. Asmund 1956 is a species of another section. It was described as having short bristles at the rear end which bear curiously shaped hooks. Under the electron microscope these hooks can be seen in unmistakable detail. Sometimes, however, imperfect forms occur in which these hooked bristles are absent and the long straight bristles normally occurring at the anterior portion may occur all round the organism. Electron micrographs Pl. 2, fig. 7, 8 illustrate the imperfect and the perfect forms. There are drawings of Mallomonas under various names which might be hookless forms of $M$. heterospina.

Mallomonas akrokomos Pascher of another section was diagnosed by its shape, its 6 to 8 anterior bristles and its size. The scales are so small that they were barely seen clearly until the advent of the electron microscope. Several similar species or varieties have been described since 19I3 (see below) which differ in the number and length of the bristles and length of the organism. In my experience the size of $M$. akrokomos from the same pond may vary greatly, the largest form appearing early in the year and the smaller ones during swarming and before encystment. The number of bristles varies from eight down to none, and of such bristles as are present a variable number may be long and others short. This variation is met both in large and in small cells (Harris, 1958, p. 61). An imperfect form not figured before is shown in Fig. I $c$. It is unusual in lacking the long tail formed by two attenuated scales. I imagine it is an individual recently produced by cell division. When a Mallomonas divides it loses all its old scales and new ones appear on the daughter cells. But this organism has not yet produced its rear scales. Such organisms have been seen occasionally in a few ponds where $M$. akrokomus is swarming.

The following species and varieties may well be imperfect forms of Mallomonas 
akrokomos: M. pauciseta Nauman; M. quadricornis Wermel; M. akrokomos var. parvula Conrad; M. paucispina Conrad. See Huber-Pestalozzi (1941) or Matvienko (1965) for figures and further references.

Mallomonas insignis Penard of another section; see Harris (1958) for e.m. illustrations and for imperfect forms. It is very common in some ponds near Reading, Berkshire, England. Its scale proves constant but imperfect forms of cell which look very unusual, are frequent. I suggest that the following species may be imperfect forms of $M$. insignis since the published figures look very much like my own drawings: $M$. torulosa Kisselew; $M$. insignis var. lacustris Bourrelly; $M$. mesolepis Skuja; $M$. mesolepsis var. spinosa Matvienko (see Huber-Pestalozzi, 194I, or Matvienko, I965, for figures and further references).

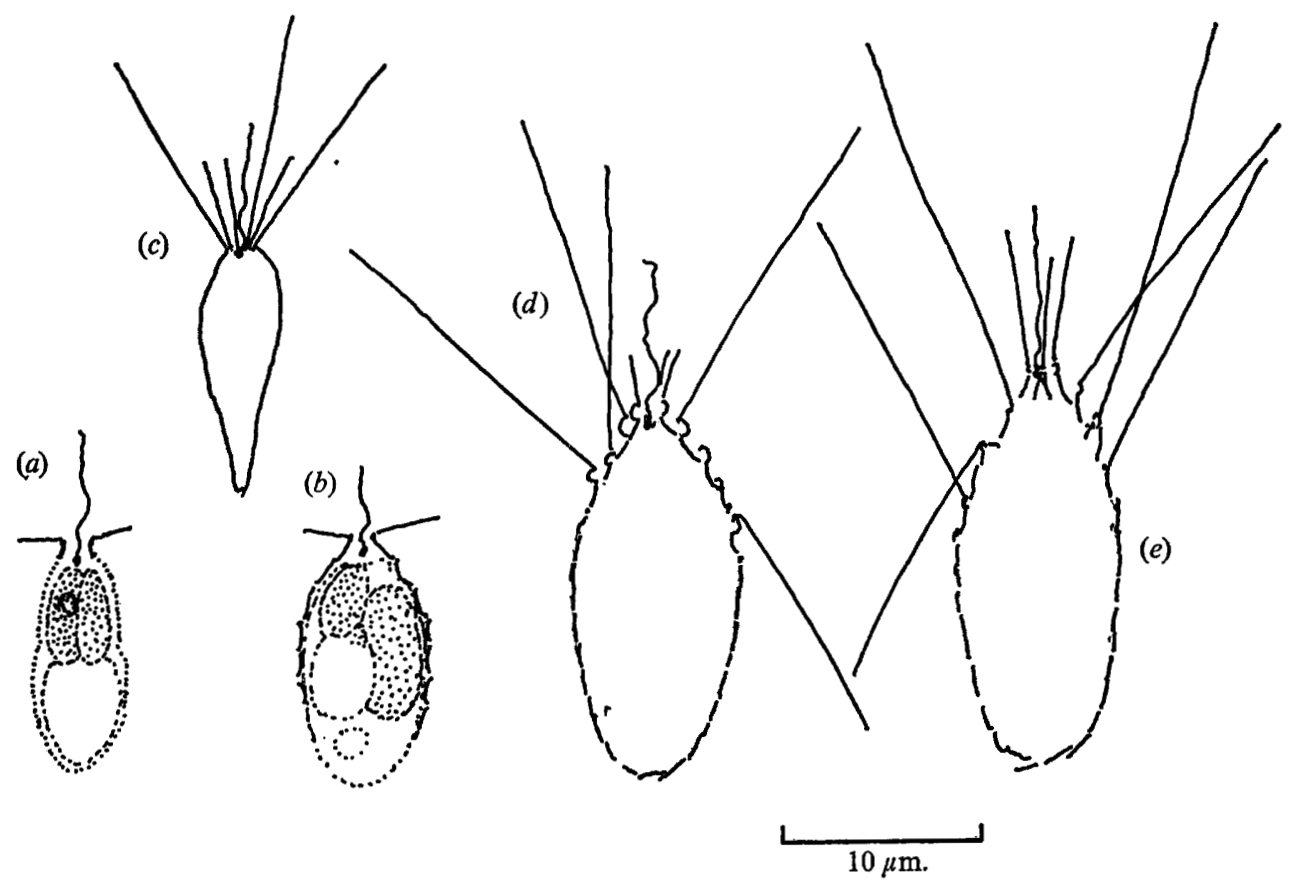

Fig. I. (a) Imperfect form of Mallomonas pumilio, possibly occurring soon after germination. (b) Imperfect form of $M$. pumilio, at a later stage than (a). (c) Imperfect form of $M$. akrokomos which lacks two long rear scales. (d) Imperfect form of $M$. tonsurata lacking rear bristles. (e) Imperfect form of $M$. intermedia lacking rear bristles.

In the section tripartitae, the acaroides group is particularly difficult taxonomically. One of the main characters supposed to distinguish the species is the fraction of the cell covered by bristle-bearing scales but even in a species which normally has bristles all over, imperfect forms occur without bristles at the rear. The bristles themselves have specific characters and in imperfect forms they may be simpler than normal. For example, the perfect cell of Mallomonas intermedia of this group has bristles all over but that of $M$. tonsurata var. alpina lacks them at the rear. Another difference is that $M$. intermedia has bristles with refractive tips. In both species imperfect forms are met with bristles confined to a varying portion of the front of the organism. In $M$. intermedia these imperfect forms may lack the refractive tip to the bristle and the 
size of the imperfect forms may be the same in the two species so that they look almost alike under the light microscope. Compare Fig. I $d, M$. tonsurata, with Fig. I $e, M$. intermedia.

I thank Professor R. M. Ditchburne, F.R.S., and Professor Trevor Evans for allowing me to use the electron microscope in the J. J. Thomson Laboratory, University of Reading.

\section{REFERENCES}

ASMUND, B. (1955). Electron microscope observations on Mallomonas caudata and some remarks on its occurrence in four Danish ponds. Botanisk Tidsskrift 52, I63.

AsMUND, B. (1956). Electron microscope observations on Mallomonas species and remarks on their occurrence in some Danish ponds. II. Botanisk Tidsskrift 53, 75.

FotT, I. B. (1955). Scales of Mallomonas observed in the electron microscope. Preslia 27, 280.

HARRIS, K. (1958). A study of Mallomonas insignis and Mallomonas akrokomos. Journal of General Microbiology 19, 55.

Huber-PestalozzI, G. (194I). Die Binnengewässer. Das Phytoplankton des Süsswassers 16, ror.

LUND, J. W. G. (1942). Contributions to our knowledge of British Chrysophyceae. New Phytologist 4I, 274.

MATVIENKO, O. M. (1965). Identification key of the freshwater algae of the Ukrainian R.S.R. III Chrysophyta. Ukrainian Academy of Science and Botany, Publishing House Kiev.

\section{EXPLANATION OF PLATE}

Plate I

Fig. I. Direct electron micrograph of perfect cell armour of Mallomonas pumilio. $\times 4300$. Unfixed material, cytoplasm removed.

Fig. 2. Replica of cell armour of $M$. pumilio var. slightly damaged at rear. One rear scale shows a small point. $\times 4300$. Unfixed material.

Fig. 3. Replica of armour of imperfect form of $M$. pumilio var. $\times 4300$. Unfixed material.

Fig. 4. Replica of imperfect form of $M$. pumilio var. $\times 4300$. Fixed in vapour of osmium tetroxide.

Fig. 5. Direct electron micrograph of imperfect form of $M$. mangofera $\times 4300$. Unfixed material, cytoplasm removed.

Fig. 6. Replica of perfect form of $M$. mangofera. $\times 4300$. Unfixed material.

\section{Plate 2}

Fig. 7. Direct electron micrograph of imperfect cell of $M$. heterospina $\times 5000$. Material fixed in osmium tetroxide vapour, cytoplasm removed.

Fig. 8. Direct electron micrograph of perfect cell of $M$. heterospina. $\times 5000$. Fixed osmium tetroxide vapour. 
Journal of General Microbiology, Vol. 6I, No. I

Plate I
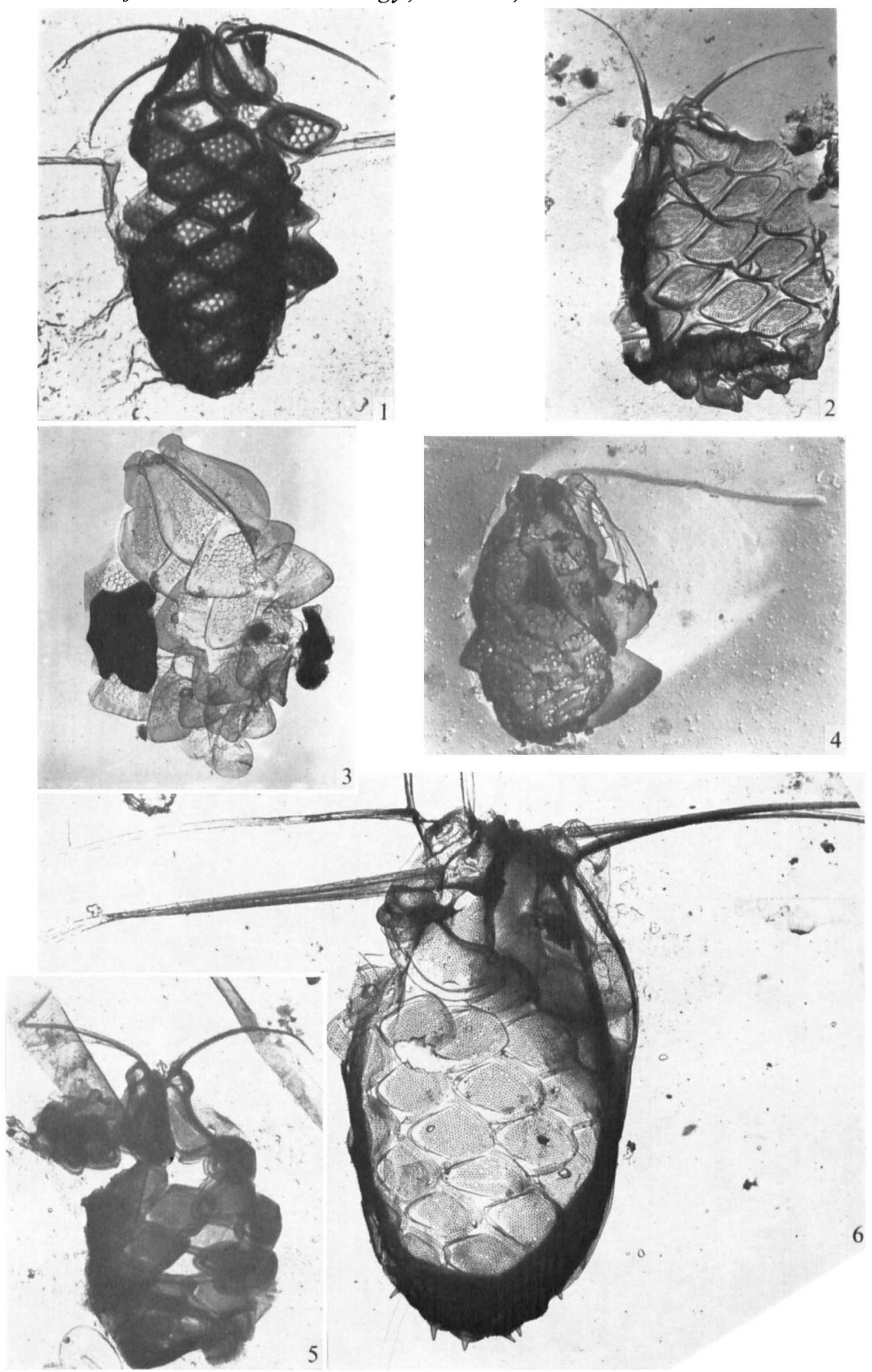

K. HARRIS

(Facing p. 76) 
Journal of General Microbiology, Vol. 6I, No. I

Plate 2
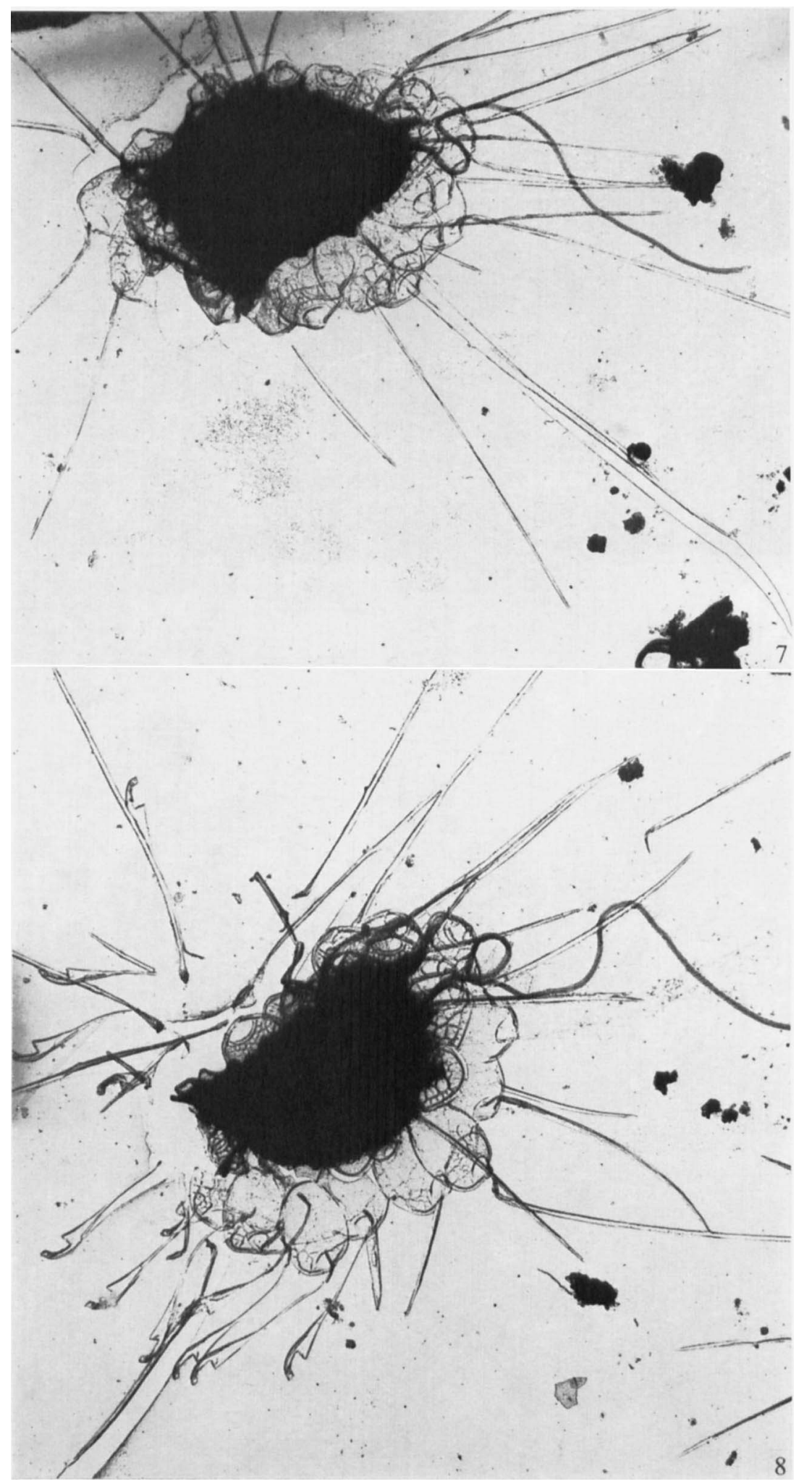

K. HARRIS 